\title{
Endocannabinoid receptors contribute significantly to multiple forms of long-term depression in the rat dentate gyrus
}

\author{
Christine J. Fontaine, ${ }^{1}$ Erin L. Gräfe, ${ }^{1}$ Cristina Pinar, ${ }^{1}$ Itziar Bonilla-Del Río, ${ }^{2,3}$ \\ Pedro Grandes, ${ }^{1,2,3}$ and Brian R. Christie ${ }^{1,4}$ \\ ${ }^{1}$ Division of Medical Sciences, University of Victoria, Victoria, British Columbia V8W 2Y2, Canada; ${ }^{2}$ Department of Neurosciences, \\ Faculty of Medicine and Nursing, University of the Basque Country UPV/EHU, E-48940 Leioa, Spain; ${ }^{3}$ Achucarro Basque Center for \\ Neuroscience, Science Park of the University of the Basque Country UPV/EHU, E-48940 Leioa, Spain; ${ }^{4}$ Island Medical Program and \\ Department of Cellular and Physiological Sciences, University of British Columbia, Victoria, British Columbia, USA
}

\begin{abstract}
Cannabinoid receptors are widely expressed throughout the hippocampal formation, but are particularly dense in the dentate gyrus (DG) subregion. We, and others, have shown in mice that cannabinoid type 1 receptors (CBIRs) are involved in a long-term depression (LTD) that can be induced by prolonged $10 \mathrm{~Hz}$ stimulation of the medial perforant path (MPP)granule cell synaptic input to the DG. Here, we extend this work to examine the involvement of CBIRs in other common forms of LTD in the hippocampus of juvenile male and female Sprague-Dawley rats (Rattus norvegicus). We found, as in mice, that prolonged $10 \mathrm{~Hz}$ stimulation (6000 pulses) could reliably induce a form of LTD that was dependent upon CBIR activation. In addition, we also discovered a role for both CBIR and mGluR proteins in LTD induced with $1 \mathrm{~Hz}$ lowfrequency stimulation (1 Hz-LTD; 900 pulses) and in LTD induced by bath application of the group I mGluR agonist (RS)-3,5-Dihydroxyphenylglycine (DHPG; DHPG-LTD). This study elucidates an essential role for endocannabinoid receptors in a number of forms of LTD in the rat DG, and identifies a novel role for CBIRs as potential therapeutic targets for conditions that involve impaired LTD in the DG.
\end{abstract}

Long-term depression (LTD) of synaptic efficacy is a process that can selectively weaken communication at specific synapses, as well as play a role in synapse elimination. Early studies showed that monocular deprivation both reduced synaptic activity and enhanced synapse elimination in visual cortex (Hubel et al. 1977). This is also an activity-dependent process, as preventing cells from firing action potentials can block synapse elimination (Stryker and Harris 1986). LTD was initially classified as being either activity-dependent (homosynaptic) or activity-independent (heterosynaptic; Christie et al. 1994). Homosynaptic LTD was reliably induced by the application of low-frequency stimuli, either alone (Dudek and Bear 1992), or in association with highfrequency stimulation to a spatially segregated input to the same population of cells (Stanton and Sejnowski 1989; Christie and Abraham 1992a). Heterosynaptic LTD is observed in synapses that are proximal to, but spatially segregated from, synapses where LTP induction has occurred (Christie and Abraham 1992b). Despite the nomenclature, it was fairly well accepted that both forms of LTD required some degree of postsynaptic depolarization (Christie et al. 1994, 1995), and this helped direct studies that elucidated functional roles for LTD. A role for LTD in structural plasticity emerged as evidence accumulated showing that the induction of LTD was associated with the loss, or shrinkage, of dendritic spines (Bastrikova et al. 2008; Wiegert and Oertner 2013). This work was important, as it provided a biologically relevant association between LTD and synapse elimination. In addition, studies also began to show that LTD of a synapse could also provide a

Corresponding author: brain64@uvic.ca

Article is online at http://www.learnmem.org/cgi/doi/10.1101//m.050666.119. meaningful way to increase storage capacity in neurons (Safaryan et al. 2017), and increase the signal to noise ratio between synapses, without synapse elimination.

Given the potential roles for LTD in these diverse structural and functional processes, it should not be surprising that the mechanisms that contribute to LTD induction and expression can be equally diverse and exhibit regional specificity (Pinar et al. 2017). For instance, the induction of homosynaptic LTD at glutamatergic synapses in the CA1 region appears to be primarily mediated by the activation of N-methyl-D-aspartate receptors (NMDARs) and/or metabotropic glutamate receptors (mGluRs), involves a modest rise in intracellular calcium, and results in the subsequent internalization of $\alpha$-amino-3-(5-methyl-3-oxo-1,2-oxazol4-yl) propanoic acid receptors (AMPAR; Mulkey and Malenka 1992; Mulkey et al. 1993, 1994; Bear and Malenka 1994; Christie 1996; Cummings et al. 1996; Christie et al. 1997; Lee et al. 1998; Man et al. 2000; Ahmadian et al. 2004; Liu et al. 2004; Malenka and Bear 2004). In contrast, the role of NMDA receptors in activitydependent forms of LTD in the dentate gyrus (DG) have been more elusive, and the involvement of NMDARs remains equivocal. Indeed, LFS has been repeatedly shown to induce NMDARindependent forms of LTD in the rat DG (O'Mara et al. 1995; Trommer et al. 1996; Wang et al. 1997; Pöschel and Manahan-Vaughan 2007; Pöschel and Stanton 2007; Vasuta

(C) 2020 Fontaine et al. This article is distributed exclusively by Cold Spring Harbor Laboratory Press for the first 12 months after the full-issue publication date (see http://learnmem.cshlp.org/site/misc/terms.xhtml). After 12 months, it is available under a Creative Commons License (Attribution-NonCommercial 4.0 International), as described at http://creativecommons.org/licenses/by-nc/ $4.0 /$ 
et al. 2007) in both in vitro and in vivo preparations. While the initial induction mechanisms remain elusive, a requirement for some degree of postsynaptic depolarization and a modest rise in calcium have been reported (Christie and Abraham 1994; Trommer et al. 1996; Christie et al. 1997). In addition to a potential role for NMDAR's, pharmacological activation of group I mGluRs (O'Mara et al. 1995) and the endogenous cannabinoid signaling system (endocannabinoids, eCBs) have also been shown to be involved in specific forms of LTD in the DG (Peñasco et al. 2019, 2020). Because the cannabinoid type 1 receptor (CB1R) is localized throughout the DG (Gutiérrez-Rodríguez et al. 2017), and these receptor proteins are well positioned to impact multiple forms of synaptic plasticity, we sought to determine if there was a role for CB1Rs in different forms of LTD in the DG.

\section{Results}

$\mathrm{CB} 1$ receptors are located on various neuronal and non-neuronal substrates in the dentate gyrus

Regions from the dentate molecular layer of juvenile rats were examined to investigate the cellular and subcellular localization of the CB1 receptor (Fig. 1). Astrocytes and their processes were identified by DAB immunodeposits of GFAP and the CB1 receptor was detected by immunogold labeling. As expected, presynaptic inhibitory terminals that formed symmetric synapses highly expressed CB1 receptor immunoparticles. In contrast, labeling was less abundant at excitatory terminals that formed asymmetric synapses with dendritic spines, as well as on astrocytic and mitochondrial membranes.

\section{LTD induced by $10 \mathrm{~Hz}$ stimulation is dependent on $\mathrm{mGluR}_{5}$ and CBIR}

In the initial experiments we sought to determine if administering a LFS train of 6000 pulses at $10 \mathrm{~Hz}$ could reliably induce LTD in the juvenile rat DG. We found that the $10 \mathrm{~Hz}$ LFS induced a significant and immediate short-term depression (STD; $-78.25 \pm 3.96 \%, \quad P=$ $3.12 \times 10^{-5} ; n=16$ slices from seven animals) that transitioned into a longerlasting (60 min) LTD of MPP evoked synaptic responses $(-18.74 \pm 3.50 \% ; \quad P=$ $0.00020 ; n=16$ slices from seven animals; Fig. 2). The induction of LTD with the $10 \mathrm{~Hz}-\mathrm{LFS}$ had no effect on pairedpulse ratios $(P=0.22)$, indicating that this LTD does not alter presynaptic neurotransmitter release probability. In agreement with results obtained in mice (Peñasco et al. 2019), the LTD induced by the $10 \mathrm{~Hz}$ LFS could be blocked by the CB1 inverse agonist, N-(Piperidin-1-yl)-5-(4-iodophenyl)-1(2,4-dichlorophenyl)-4-methyl-1H-pyra-
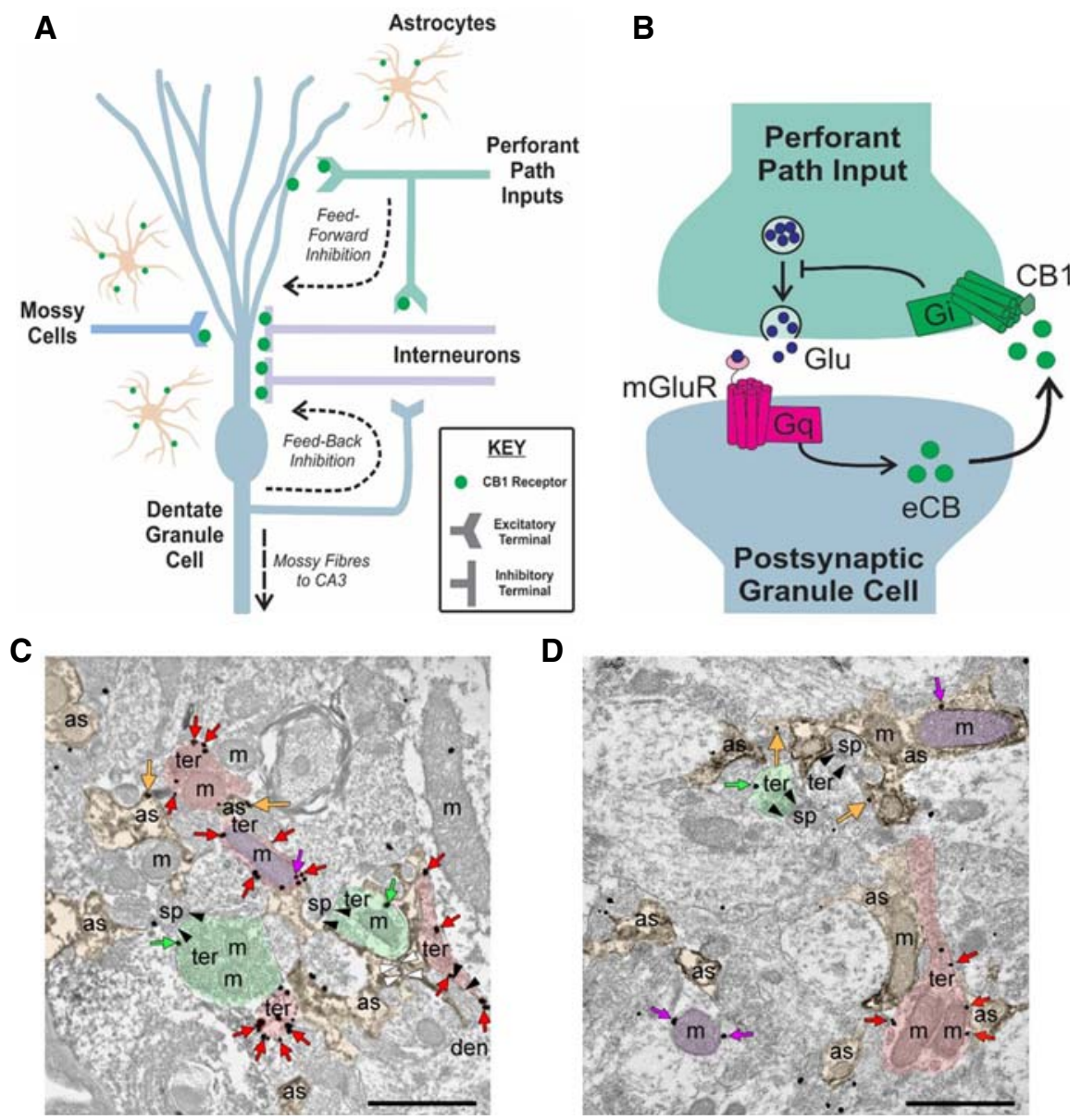

Figure 1. Cannabinoid type $1(C B 1)$ receptors are located throughout the $D G$ and participate in longterm synaptic depression. ( $A$ ) Schematic summarizing localization of $C B 1$ receptors in the rodent DG circuitry. CB1 receptors (green dots) have been previously found to exist on presynaptic perforant path axon terminals, which provide glutamatergic input to DG granule cells. Local interneurons that are involved in feedforward inhibition (inputs from perforant path) and feedback inhibition onto DG granule cells also express $C B 1$ receptors. These receptors can also be found on mossy cells terminals, unique glutamatergic neurons of the DG as well as on astrocytes. Endocannabinoids are thus positioned to play roles in various forms of synaptic activities, including synaptic plasticity. (B) Simplified hypothesized mechanism of long-term depression dependent on $C B 1$ receptor function in the DG. Stimulation of perforant path inputs at $6000 \times 10 \mathrm{~Hz}$ under conditions where $\mathrm{GABA}_{\mathrm{A}}$ is inhibited, leads to glutamate (Glu) release that binds to group 1 metabotropic glutamate receptors (mGluRs) coupled to $\mathrm{G}_{\mathrm{q}}$-proteins that initiate a second messenger signaling cascade culminating in the on-demand synthesis of endocannabinoids (eCBs). Endocannabinoids diffuse out of the postsynaptic membrane to activate presynaptic CB1 receptors on perforant path terminals. The $C B 1$ receptors are Gi-coupled receptors and their activation leads to a reduction in presynaptic neurotransmitter release and therefore a reduction in synaptic efficacy characteristic of LTD. $(C, D)$ Subcellular localization of $C B 1$ receptors in rat DML. Preembedding immunogold/immunoperoxidase method. CB1 receptor immunolabeling is observed on excitatory terminals (ter, green arrows), inhibitory terminals (ter, red arrows), astrocytic membranes (as, orange arrows) as well as neuronal and astrocytic mitochondria ( $m$, purple arrows). 

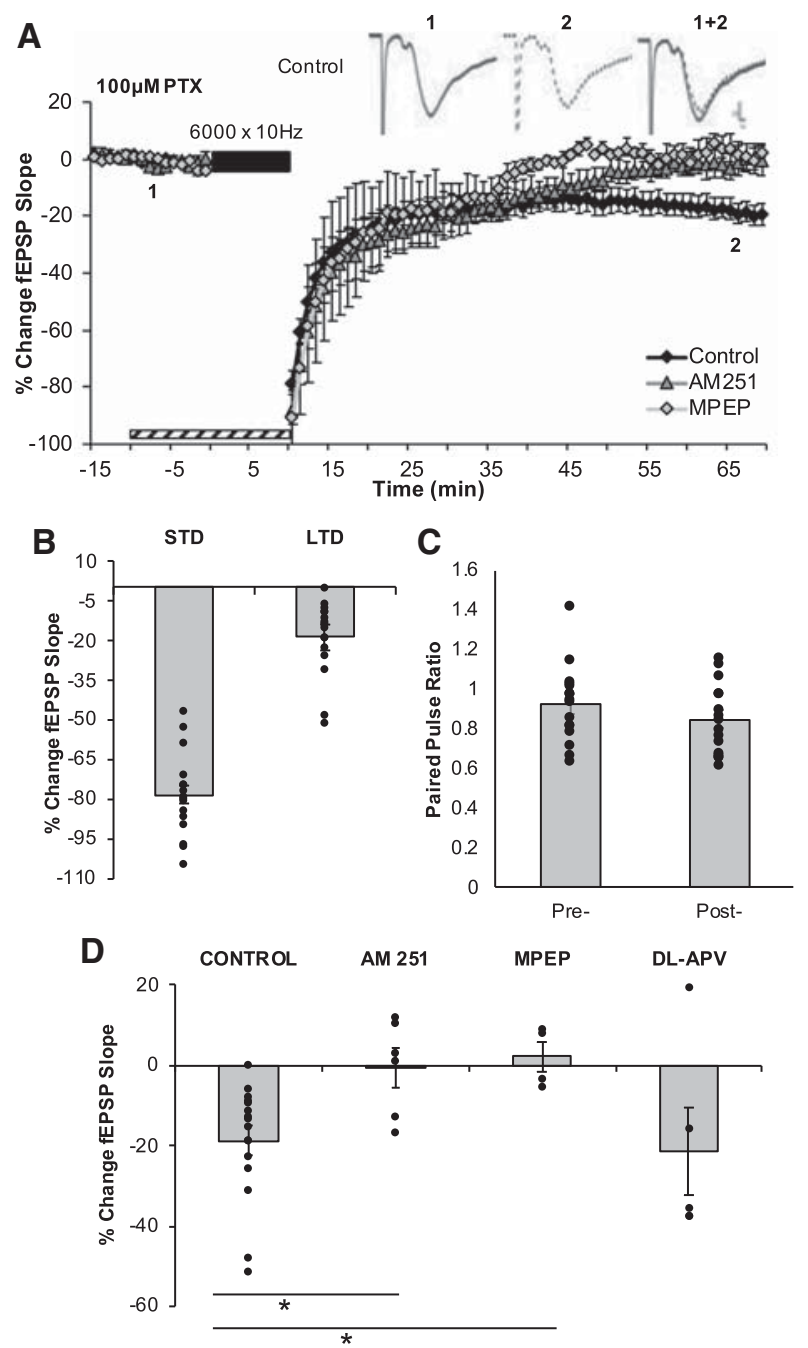

Figure 2. $6000 \times 10 \mathrm{~Hz}$ LFS induces $\mathrm{CB} 1 \mathrm{R}$ and $\mathrm{mGluR}_{5}$-dependent LTD. (A) LTD was measured as the average percentage of change in the fEPSP slope relative to baseline for minutes $65-75$ as a result of the delivery of the $6000 \times 10 \mathrm{~Hz}$ LFS (indicated as black bar). Striped bar represents the duration of exposure of pharmacological inhibitors. Numbers 1 and 2 indicate the relative timing that corresponds to the representative traces in A. All recordings took place in the presence of $100 \mu \mathrm{M}$ picrotoxin (PTX)-containing aCSF. Representative field excitatory postsynaptic potentials (fEPSPs) are displayed in the upper right corner illustrating the preconditioning period ( 1 , solid black line) and the end of the postconditioning recording (2, dotted black line). Scale represents $0.2 \mathrm{mV}$ by $1 \mathrm{msec}$. (B) The average magnitudes of short term depression (STD) and LTD are indicated as the first minute and the last $5 \mathrm{~min}$ of the postconditioning recordings, respectively. Bars represent the average LTD $(-18.75 \pm 3.50 \%$, $n=16$ slices) induced by $6000 \times 10 \mathrm{~Hz}$ in the control data set. Dots represent the average amounts of STD and LTD for each slice that make up this data set. (C) The paired pulse ratios evaluated before the induction of LTD and at the end of the postconditioning recording were not statistically significantly different, providing indications that this LTD is not mediated by a change to presynaptic neurotransmitter release probability. (D) Pharmacological inhibition of CB1R $(-0.55 \pm 4.47 \%, n=6$ slices, $P=$ $0.012)$ or mGluR $_{5}(2.07 \pm 3.71 \%, n=4$ slices, $P=0.0026)$ but not NMDARs $(-21.45 \pm 10.96 \%, n=6$ slices, $P=0.82)$ block the maintenance of $6000 \times 10 \mathrm{~Hz}$-LTD. Dots represent the average amounts of LTD for each slice that make up the average (indicated as the bar) for each group. Error bars throughout represent the standard error of the mean. Statistical significance was achieved by a two-tailed $t$-test compared against control and $P<0.05$ is indicated by a *.

\section{LTD induced in the DG by $1 \mathrm{~Hz}$ stimulation involves $\mathrm{CB}$ 1 receptors}

The delivery of 900 pulses at $1 \mathrm{~Hz}$ induced significant de novo STD $\left(-46.30 \pm 4.67 \%\right.$ LTD; $n=11$ slices, eight animals; $\left.P=1.79 \times 10^{-6}\right)$ and LTD $(-24.85 \pm 4.30 \%$ LTD; $n=11$ slices, 8 animals; $P=$ 0.000216 ; Fig. 3) in the DG. While $10 \mathrm{~Hz}$ and $1 \mathrm{~Hz}$-induced similar magnitudes of LTD $(P=0.288)$, the $1 \mathrm{~Hz}$ LFS induced significantly less STD than was observed with the $10 \mathrm{~Hz}$ stimuli $\left(P=3.12 \times 10^{-5}\right.$; $d=0.52$ ), likely reflecting the difference in the number of stimuli administered (10,000 vs. 900). As with the LTD induced by the $10 \mathrm{~Hz}$ stimuli, the LTD induced by $1 \mathrm{~Hz}$ LFS did not alter pairedpulse ratios $(P=0.52)$, suggesting that this LTD also did not involve a change in presynaptic release probability. In contrast, while $\mathrm{GABA}_{\mathrm{A}}$ antagonist picrotoxin (PTX; $100 \mu \mathrm{M}$ ) was required for the induction of LTD with the $10 \mathrm{~Hz}$ stimuli, it did not have any effect on the magnitude of LTD induced by the $1 \mathrm{~Hz}$ LFS $(-27.59 \pm 6.60 \%$; $n=9$ slices, four animals; $P=0.509$; data not shown).

To determine if the $10 \mathrm{~Hz}$ stimuli and the $1 \mathrm{~Hz}$ stimuli induced LTD that required the activation of similar receptors, we examined the capacity for the $1 \mathrm{~Hz}$ LFS to induce LTD in the presence of MPEP (-20.15 $\pm 6.40 \% ; n=6$ slices, four animals), AM 251 $(-15.83 \pm 6.24 \% ; n=17$ slices, eight animals) or DL-APV $(-26.68$ $\pm 5.11 \% ; n=6$ slices, three animals). In each case, blocking either mGluR, CB1, or NMDA receptors alone had no effect on the magnitude of $1 \mathrm{~Hz}$-LTD $(P=0.789 ; P=0.556 ; P=0.17)$. Similarly, inhibiting L-type calcium channels with nimodipine $(20 \mu \mathrm{M})$ also failed to block $1 \mathrm{~Hz}$-induced LTD $(-26.80 \pm 2.88 \% ; n=2$ slices, two animals; $P=0.731$ ). Surprisingly, preventing the phosphorylation of tyrosine residues on the GluA2 subunit $\left(10 \mu \mathrm{M}\right.$ Tat-GluA2 $2_{3 y}$ peptide), thought to be critical for AMPAR endocytosis (Man et al. 2000; Ahmadian et al. 2004) failed to block $1 \mathrm{~Hz}-\mathrm{LTD}$ in the DG with the LFS stimulation $(-22.79 \pm 1.63 \%$; $n=6$ slices, four animals; $P=0.235$ ). A complete blockade of the LTD induced by the $1 \mathrm{~Hz}$ LFS was only reliably observed in the presence of both AM 251 and MPEP simultaneously $(-0.82 \pm 4.14 \% ; n=10$ slices, six animals; $P=0.000548$; effect size $d=1.75$ ). These data indicate that both mGluR and CB1 receptors are involved in LTD induced by both stimulation paradigms, however inhibition of both receptors are required to block $1 \mathrm{~Hz}$ LTD whereas inhibition of either receptor alone is sufficient to block $10 \mathrm{~Hz}$-induced LTD.

Since both $\mathrm{CB} 1$ and $\mathrm{mGluR}_{5}$ receptors appear to be necessary for the induction of LTD in the DG, we sought to determine if the induction of LTD with $10 \mathrm{~Hz}$ stimulation (6000 pulses) would occlude, or reduce, the induction of LTD with the $1 \mathrm{~Hz}$ LFS (900 pulses). The application of the $10 \mathrm{~Hz}$ stimuli induced a robust LTD $(-21.23 \pm 3.67 \%)$, however the subsequent application of the $1 \mathrm{~Hz}$ stimuli resulted in significantly more LTD being induced $(\sim-17 \%)$ for a combined LTD magnitude of $-37.99 \pm 5.02 \%(n=11$ slices, six animals; $P=0.00176$; Fig. 4$)$. There was a large effect size for the amount of LTD induced by the $1 \mathrm{~Hz}$ LFS following 10 Hz-LTD $(d=1.15)$ induction, indicating that both of these two stimulus paradigms may be recruiting mGluR and CB1 receptors.

\section{Chemical DHPG-induced mGluR-LTD is also dependent on the CBIR}

To better determine the role of mGluR receptors in LTD in the DG, we first sought to pharmacologically induce mGluR-dependent LTD by bath applying (RS)-3,5-Dihydroxyphenylglycine (DHPG; $30 \mu \mathrm{M})($ Camodeca et al. 1999). The bath application of DHPG reliably induced a persistent de novo LTD of synaptic efficacy $(-21.96$ $\pm 3.68 \% ; P=0.00055 ; n=8$ slices, five animals; Fig. 5 ). When DHPG was coapplied with AM 251 the LTD was abolished $(-0.44 \pm 3.20 \%$; $n=5$ slices, four animals; $P=0.001 ; d=2.30$ ). Similarly, coapplication with MPEP led to a significant attenuation of the synaptic 

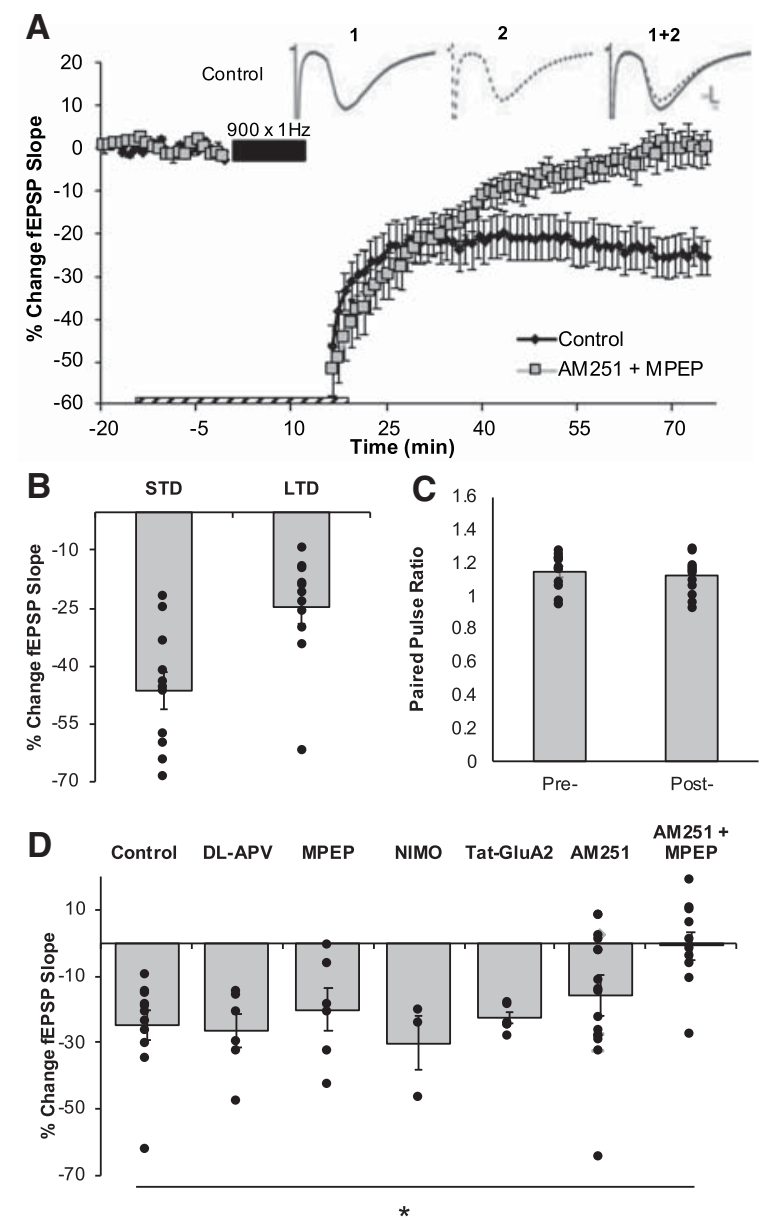

Figure 3. $900 \times 1 \mathrm{~Hz}-\mathrm{LFS}$ induced LTD is dependent on coactivation of mGluR $_{5}$ and CB1R. (A) LTD was measured as the average percentage of change in the fEPSP slope relative to baseline for minutes 70-75 as a result of the delivery of the $900 \times 1 \mathrm{~Hz}$ LFS (indicated as black bar). Dashed bar represents the duration of exposure of pharmacological inhibitors. Numbers 1 and 2 indicate the relative timing that corresponds to the representative traces. Representative field excitatory postsynaptic potentials (fEPSPs) from the preconditioning period ( 1 , solid black line) and from the end of the postconditioning recording (2, dotted black line). Scale represents $0.2 \mathrm{mV}$ by $1 \mathrm{msec}$. (B) The average magnitudes of STD and LTD are indicated as the last $5 \mathrm{~min}$ of the postconditioning recordings. Bars represent the average LTD $(-24.85 \pm 4.30 \%, n=11$ slices) induced by $900 \times 1 \mathrm{~Hz}$ in the control data set. Dots represent the average amounts of STD and LTD for each slice that make up this data set. (C) The paired pulse ratios evaluated before the induction of LTD and at the end of the postconditioning recording were not statistically significantly different, providing indications that this LTD is not mediated by a change to presynaptic neurotransmitter release probability. (D) Pharmacological inhibition of NMDAR $(-26.68 \pm 5.11 \%, n=6$ slices, $P=0.789), \operatorname{mGluR}_{5}(-20.15 \pm$ $6.40 \%, n=6$ slices, $P=0.556$ ), L-type calcium channels (Nimodipine, NIMO; $-26.80 \pm 2.88 \% ; n=2$ slices, $P=0.731$ ), Tyr phosphorylation on AMPARs (Tat-GluA2 3 ; $-22.79 \pm 1.63 \% ; n=6$ slices, $P=0.235$ ) or CB1R $(-15.83 \pm 6.24 \%, n=17$ slices, $P=0.173)$ independently had no effect on this LTD. Combined inhibition of mGluR $_{5}$ and CB1R led to a significant blockade of $\operatorname{LTD}(-0.82 \pm 4.14 \%, n=10$ slices, $P=0.00055)$. Dots represent the average amounts of LTD for each slice that make up the average (indicated as the bar) for each group. Error bars throughout represent the standard error of the mean. Statistical significance was achieved by a two-tailed t-test compared against control and $P<0.05$ is indicated by $a *$.

depression MPEP $(-10.18 \pm 3.50 \% ; n=9$ slices, five animals; $P=$ $0.035 ; d=1.13)$. The induction of the mGluR-dependent LTD did not occlude further LTD induced by $1 \mathrm{~Hz}$ LFS $(-41.86 \pm 4.97 \%$; $n$ $=8$ slices, five animals; $P=0.00506 ; d=1.61$ ), indicating that while these forms of synaptic depression recruit overlapping mechanisms they are distinct.

\section{Pharmacological activation of CB1 receptors induces LTD}

To determine whether LTD can be induced solely by activation of CB receptors, we pharmacologically activated these receptors with Win-55, 212-2 (Win, $5 \mu \mathrm{M}$ ), a high affinity agonist of CB1 but with agonist properties for the lesser-expressed CB2 receptors in the DG (Peñasco et al. 2019). Bath application of Win alone caused a significant depression in synaptic efficacy $(29.6 \pm 7.49 \% ; n=4$ slices, one animal; $P=0.024$; Fig. 6). These data provide evidence that CB1 receptor activity alone is sufficient in inducing synaptic depression in the juvenile rat DG.

\section{Discussion}

The present results reveal a significant role for the eCB signaling system, in conjunction with $\mathrm{mGluR}_{5}$ receptors, in multiple forms of LTD in the DG. Furthermore, despite the overlapping involvement of mGluR $_{5}$ and CB1Rs in the forms of LTD examined in this study, each form of LTD failed to occlude the others, indicating they may also possess distinct induction mechanisms.
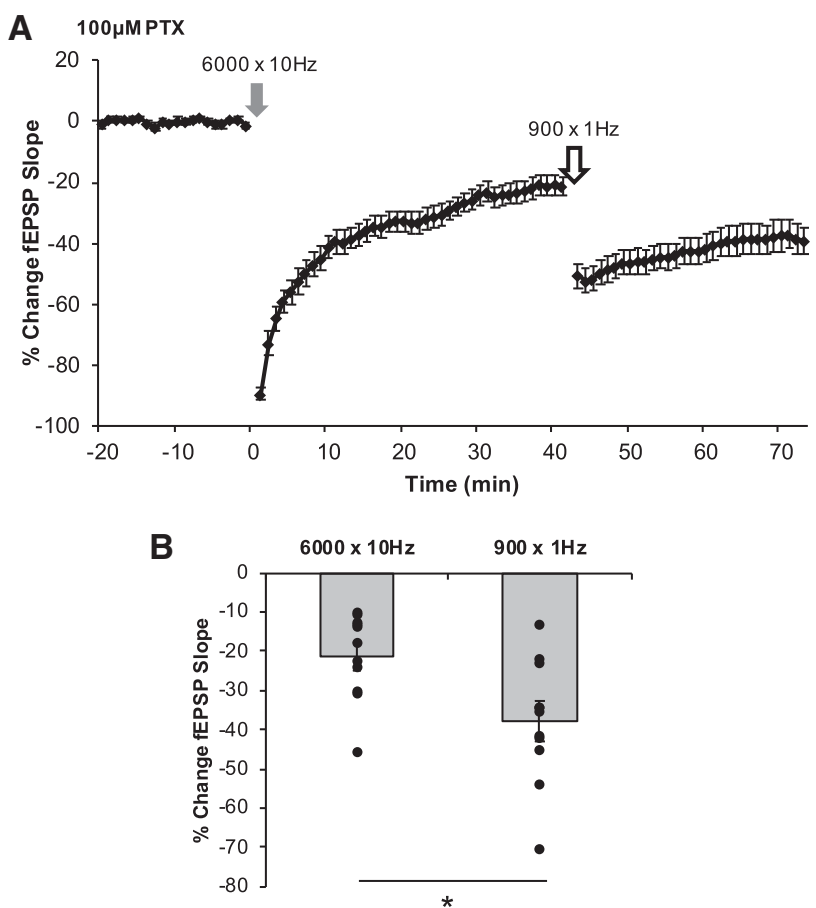

Figure 4. Establishment of LTD by $6000 \times 10 \mathrm{~Hz}$ does not occlude further LTD induced by $900 \times 1 \mathrm{~Hz}$. The magnitudes of LTD by any form of conditioning stimulus were determined from the average percent change in the fEPSP slope of the last $5 \mathrm{~min}$ of each postconditioning recording relative to the original baseline. ( $A$ ) Following $40 \mathrm{~min}$ of postconditioning recordings after $6000 \times 10 \mathrm{~Hz}$ (gray arrow; A), $900 \times 1 \mathrm{~Hz}$ LFS was delivered (white arrow) followed by a second postconditioning recording for $30 \mathrm{~min}$. The average magnitudes of each LTD are represented in B for each corresponding experiment. $6000 \times 10 \mathrm{~Hz} \operatorname{LTD}(-21.23 \pm 3.67 \%, n=$ 11 slices) did not occlude further LTD by $900 \times 1 \mathrm{~Hz}$ LFS $(-37.99 \pm 5.02 \%$, $P=0.00176)$. (B) Bars represent average magnitudes of LTD induced by each conditioning stimulus. Dots represent the average amounts of LTD for each slice that make up the average (indicated as the bar) for each group. Error bars throughout represent the standard error of the mean. Statistical significance was achieved by a two-tailed $t$-test compared against control and $P<0.05$ is indicated by $a *$. 
A
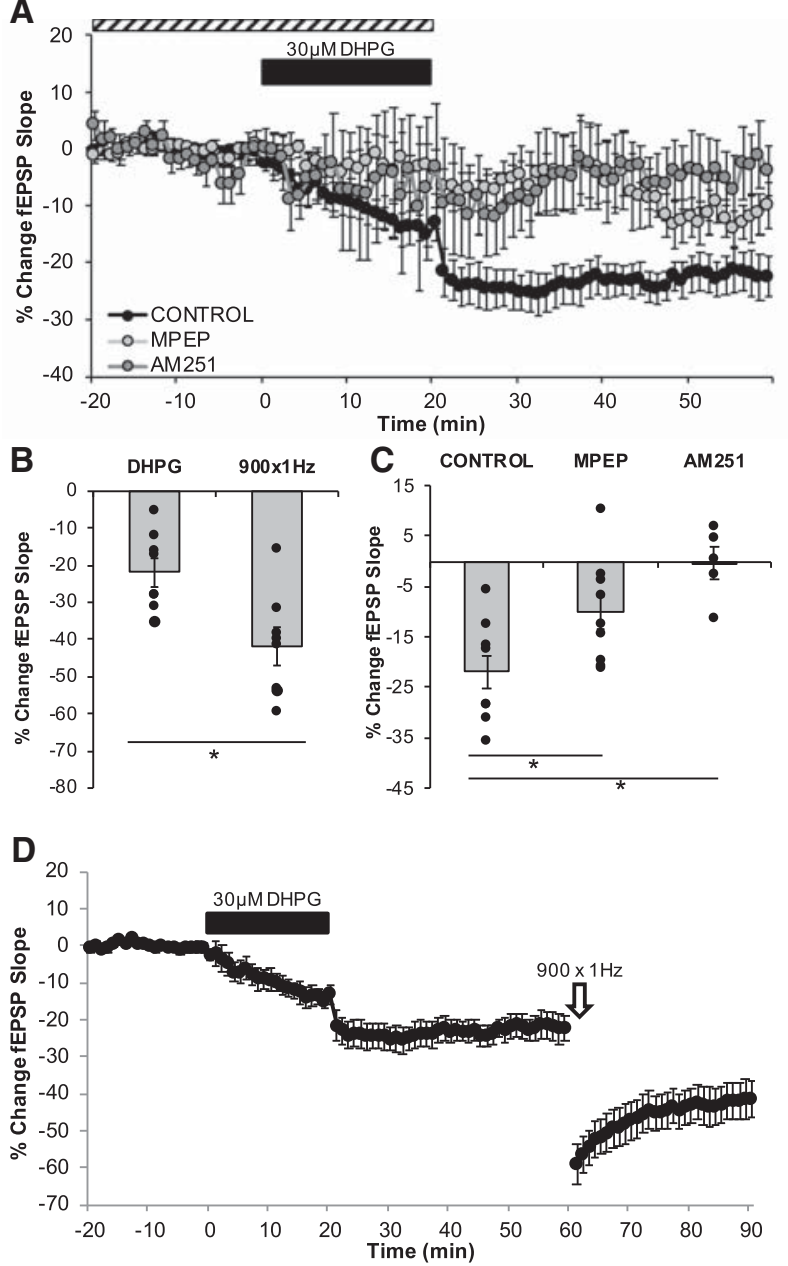

Figure 5. mGluR-LTD is also dependent on CB1R. $(A)$ LTD was measured as the average percentage of change in the fEPSP slope relative to baseline for minutes 55-60 as a result of the wash of the group I mGluR agonist DHPG $(30 \mu \mathrm{M}$, indicated as black bar). Dashed bar represents the duration of exposure of pharmacological inhibitors. $(B, D)$ Establishment of mGluR-LTD $(-21.96 \% \pm 3.68 \%, n=8$ slices $)$ does not occlude further synaptic depression by $900 \times 1 \mathrm{~Hz}$ LFS $(-41.86 \pm 4.97 \%, n=8$ slices $P=$ $0.00506)(C)$ DHPG leads to long-term depression of the fEPSP $(-21.96$ $\pm 3.68 \%, n=8$ slices) and pharmacological inhibition of $\mathrm{mGluR}_{5}$ significantly attenuated this LTD $(-10.18 \pm 3.50 \%, n=9$ slices, $P=0.035)$ while CB1R inhibition of blocked the LTD maintenance $(-0.44 \pm 3.20 \%, n=5$ slices, $P=0.001)$. Dots represent the average amounts of LTD for each slice that make up the average (indicated as the bar) for each group. Error bars throughout represent the standard error of the mean Statistical significance was achieved by a two-tailed $t$-test compared against control and $P<0.05$ is indicated by $a *$.

The endocannabinoid (eCB) system plays a role in signaling throughout the brain and we have made significant progress in understanding this system in the last $30 \mathrm{yr}$ (Wilson and Nicoll 2002a; Freund et al. 2003; Chevaleyre et al. 2006; Kano et al. 2009; Katona and Freund 2012). The CB1 receptors are G-protein coupled receptors and are the predominant cannabinoid receptor in the central nervous system. These receptors are activated by two main endogenous cannabinoids 2-arachidonoylglycerol (2-AG) and anandamide, and these receptors are widely expressed in the hippocampal formation and in particular in the DG (Gutiérrez-Rodríguez et al. 2017, 2018) (Represented in Fig. 1). As CB1 receptors have been primarily shown to be located presynaptic; they have been classically thought to regulate synaptic function through retrograde eCB signaling. We now know that eCBs are involved in many aspects of neurotransmission, from retrograde to non-retrograde as well as astrocytic signaling mechanisms (Castillo et al. 2012; Han et al. 2012; Araque et al. 2017). While predominantly located at inhibitory terminals, the CB1Rs at the glutamatergic terminals in the DG actively participate in LTP (Wang et al. 2016, 2018) and LTD of synaptic efficacy (Peñasco et al. 2019).

A growing body of literature, including the present study provide evidence that CB1Rs at glutamatergic synapses clearly play unique roles in supporting synaptic plasticity at MPP synapses. Here we have shown that the application of either 10 or $1 \mathrm{~Hz}$ stimulation for prolonged periods leads to a persistent LTD of synaptic efficacy that involves mGluR $_{5}$ and CB1R activation. The LTD induced by the $10 \mathrm{~Hz}$ stimulus was not blocked by NMDAR antagonists, but could be severely attenuated by either mGluR $_{5}$ or CB1R antagonists. In previous work in the mouse DG, the $10 \mathrm{~Hz}-\mathrm{LTD}$ activated postsynaptic $\mathrm{mGluR}_{5}$, coupled to $\mathrm{G}_{\mathrm{q} / 11}$ initiated a signaling cascade that led to calcium release from intracellular stores. In this cascade, hydrolysis of phosphatidylinositol 4,5-biphosphate $\left(\mathrm{PIP}_{2}\right)$ into diacylglycerol (DAG) and inositol triphosphate $\left(\mathrm{IP}_{3}\right)$, led to the synthesis of the eCB 2-AG which can act as a retrograde signal, diffusing across the synaptic cleft to activate presynaptic CB1R (Peñasco et al. 2019). The CB1R is coupled to $G_{i / o}$ and leads to a suppression of neurotransmitter release from the presynaptic terminal (Wilson et al. 2001; Wilson and Nicoll 2002b; Chevaleyre et al. 2006; Mato et al. 2008; Katona and Freund 2012). Further, CB1R signaling has been linked with group I mGluR activation to support DG LTD induced by $10 \mathrm{~Hz}$ LFS (Simplified schematic represented in Fig. 1), however experiments are warranted to confirm that this signaling cascade is identical in the rat hippocampus. Interestingly, a complete blockade of $1 \mathrm{~Hz}-\mathrm{LTD}$ in the present study was only obtained when both CB1 and $\mathrm{mGluR}_{5}$ receptors were inhibited, and not when either receptor was blocked alone, suggesting that there may be compensatory mechanisms to support LTD when the function of only one of these receptors is inhibited pharmacologically. It is possible that other group 1 mGluRs such as the $\mathrm{mGluR}_{1}$ may be able to compensate for the loss of function of the mGluR $_{5}$. Similarly, other components of the eCB system may play a supporting role in $1 \mathrm{~Hz}-\mathrm{LTD}$ alongside CB1 such as the TRPV1 (Chavez et al. 2010). It is also important to note that astrocytic CB1 receptors may be involved in this form of synaptic plasticity.

Bath application of the group I mGluR agonist DHPG caused mGluR-LTD at the MPP synapses that we also found to be CB1R-dependent. In hippocampal CA1, DHPG-LTD is postsynaptic and dependent on AMPAR internalization, and dendritic protein synthesis (Huber et al. 2000). Though this chemically induced LTD is less-studied in the DG, here it is likely to be dependent on both mGluR $_{1}$ and mGluR $_{5}$ subunits, as similar forms of LTD can be induced by targeting either one of these group I mGluRs (Camodeca et al. 1999). Also, there are supporting data for the involvement of tyrosine kinase and protein kinase $\mathrm{C}$ (PKC) in this form LTD (Wang et al. 1998, 2007; Camodeca et al. 1999), indicating these are signaling pathways that should be examined in future studies. Furthermore, there is already some evidence for interplay between DHPG induced mGluR-LTD and CB1Rs, as blockade of these receptors impairs short term depression (transient depression immediately following the CS) in the CA1 region, although in these studies, long-lasting LTD in the CA1 was not blocked (Rouach and Nicoll 2003). It is known that DHPG can induce LTD of inhibitory postsynaptic currents (IPSCs) in hilar mossy cells without altering event amplitude, area, rise time, or decay (Hofmann et al. 2011). This LTD is dependent on CB1R activity, and requires $\mathrm{mGluR}_{1}$ but not $\mathrm{mGluR}_{5}$ activation (Hofmann et al. 2006; Nahir et al. 2010). Interestingly, eCB agonists (i.e., anandamide or Win55, 212-2) can increase miniature IPSC frequencies in mossy cells, but this increase occurs even 


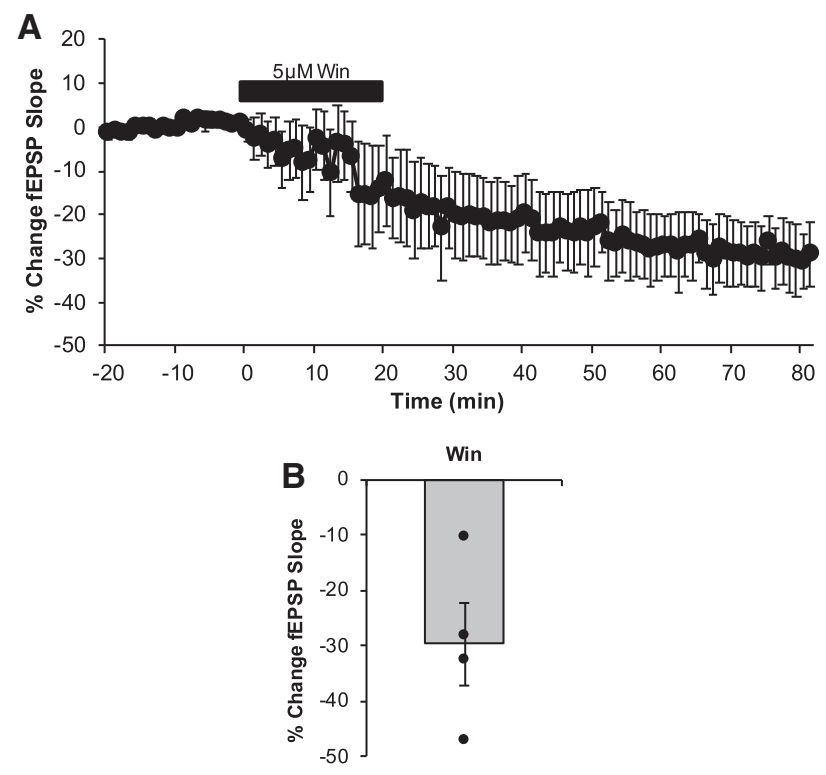

Figure 6. Direct pharmacological activation of $C B 1$ receptors induces LTD in the DG. (A) LTD was measured as the average percentage of change in the fEPSP slope relative to baseline for minutes $75-80$ as a result of the wash of the CB1 receptors agonist Win 55, 212-2 (5 $\mu \mathrm{M}$, indicated as black bar). Win exposure led to a persistent and significant depression in synaptic efficacy $(29.6 \pm 7.49 \% ; n=4$ slices, $P=0.024)$. (B) Dots represent the average amounts of LTD for each slice that make up the average (indicated as the bar). Error bars throughout represent the standard error of the mean.

during blockade of CB1Rs, CB2Rs, and TRPV1 receptors, suggesting that there may be some other targets for $\mathrm{eCB}$ agonists that have the capacity to modulate synaptic signaling (Hofmann et al. 2011). DHPG-induced LTD in the DG has been shown to occlude further synaptic depression by $6000 \times 10 \mathrm{~Hz}$ LFS (Peñasco et al. 2019). The role of GABAergic signaling cannot be ruled out in our present study, as GABAergic function was unaltered in our preparation in the DHPG-exposed slices. Thus, it is possible that DHPG could be simultaneously inducing various forms of overlapping synaptic plasticity in both glutamatergic and GABAergic circuitry of the DG. Similarly, the CB1R can be recruited pharmacologically to induce LTD of excitatory transmission as shown in the present study in the rat DG in vitro as well as in the hippocampal CA1 in vivo. In the CA1 hippocampus, a form of synaptic depression of excitatory transmission could be induced by the injection of cannabinoids, but not in the DG (Han et al. 2012). Using genetic tools, the synaptic depression observed in this study was dependent on astrocytic CB1R function, NMDAR (specifically of the NR2B) function and on AMPAR endocytosis but not on either group I or group II mGluRs (Han et al. 2012). It must be noted that Win also acts as an agonist to CB2 receptors, which are also expressed in the hippocampus although to a lesser extent than CB1 and were likely recruited in this specific pharmacological experiment (Li and Kim 2015). Independent pharmacological recruitment of these receptors is warranted in future studies as there is evidence that despite the low expression of $\mathrm{CB} 2$ receptors, they may participate in neurogenesis and in learning and memory processes (García-Gutiérrez et al. 2013; Prenderville et al. 2015).

A large number of LTD studies have focused on the LTD induced with $1 \mathrm{~Hz}$ LFS (900 pulses) in mice and rats (Dunwiddie and Lynch 1978; Dudek and Bear 1992, 1993; Mulkey and Malenka 1992). However, while NMDAR-dependent LTD is commonly induced by this LFS in the CA1, NMDAR-dependent LTD is not reported as frequently in the DG (Wang et al. 1997; Camodeca et al. 1999; Pöschel and Manahan-Vaughan 2007). There may also be species differences for the role NMDAR's play in LFS-induced LTD in mice (Vasuta et al. 2007; Eadie et al. 2012; Kannangara et al. 2014) but this has not been explored extensively in rats. Interestingly, the role of NMDAR receptors in LTD in the DG has been shown to depend on certain conditions, as specific NMDAR subunit antagonists would fail to block LTD in naïve mice, but reveal a role for GluN2A subunits in animals that exercised (Vasuta et al. 2007). Age is another important factor that appears to play a role in the magnitudes and mechanisms of LTD achievable in the hippocampus (Pinar et al. 2017). In both the CA1 and the DG, greater amounts of LTD can be achieved in the young brain as compared to adulthood, where synaptic depression is notoriously challenging to induce (Dudek and Bear 1992, 1993; Mulkey and Malenka 1992; Wang et al. 2007). It is possible that with the development and maturation of hippocampal circuits, different receptors and signaling cascades underlie different types of LTD across the lifespan. Furthermore, the recording conditions can impact the mechanisms being recruited to support LTD (Oliet et al. 1997; Nicoll et al. 1998).

These data also enhance our understanding of prior studies examining DG LTD in different pathological conditions (Pinar et al. 2017). For instance, in animal models of fetal alcohol spectrum disorders there is mounting evidence that LTD may be vulnerable to the effects of prenatal alcohol (Fontaine et al. 2016, 2019; Pierrefiche 2017), and possibly alcohol consumption in general (Peñasco et al. 2020). Indeed, the eCB system plays an important role in early neurodevelopment (Harkany et al. 2007; Taylor et al. 2007; Zhou et al. 2014) and its function may be altered by exposure to alcohol (Basavarajappa and Hungund 2002; Stringer et al. 2013; Subbanna et al. 2013, 2015; Basavarajappa 2015). It is possible that the deficits in $1 \mathrm{~Hz}$-LTD could be due to structural or functional damage to CB1R or to $\mathrm{mGluR}_{5}$ caused by the experimental manipulation (prenatal alcohol). The identification of these receptor targets for LTD in the DG can be used to direct specific analyses as to the mechanism of damage in these and other models of neurological dysfunction.

LTD in the DG is unique in that eCB signaling, particularly through CB1Rs, plays an important role in supporting LTD of excitatory neurotransmission, whether the LTD is induced by electrical or chemical stimulation protocols. This LTD is also unique in that is also shares a link with mGluR $_{5}$ signaling. Despite these overlapping mechanisms, these forms of LTD are also distinct in that they do not occlude one another, indicating that there are multiple routes available to reduce synaptic signaling at synapses in the DG.

\section{Materials and Methods}

\section{Animals}

All animal procedures were approved by, and performed in accordance with, the University of Victoria animal care committee's regulations. Sprague Dawley rats were housed in pairs or triplets under standard, unenriched conditions prior to experimental use with ad libitum access to solid rodent chow and drinking water. The facility was maintained on a 12-h light:dark cycle with lights on at 5:00 a.m.

\section{Double preembedding immunogold and}

\section{immunoperoxidase method for electron microscopy}

The method used was described previously (Puente et al. 2011). Coronal hippocampal vibratome sections were cut at $50 \mu \mathrm{m}$ and collected in 0.1 M PBS (pH 7.4) at room temperature (RT), preincubated in $10 \%$ bovine serum albumin, $0.1 \%$ sodium azide, and $0.02 \%$ saponin prepared in Tris- $\mathrm{HCl}$ buffered saline, $\mathrm{pH} 7.4$, for $30 \mathrm{~min}$ (RT) and incubated with the primary goat polyclonal 
Table 1. Pharmacological agents used in electrophysiology

\begin{tabular}{|c|c|c|c|c|c|}
\hline & Function & Vehicle & {$[$ Drug] in aCSF } & Supplier & Identifier \\
\hline Picrotoxin & Antagonist of $\mathrm{GABA}_{\mathrm{A}} \mathrm{Rs}$ & $\mathrm{dH}_{2} \mathrm{O}$ & $100 \mu \mathrm{M}$ & Tocris & P1675 \\
\hline DL-APV & competitive antagonist of NMDARs & $\mathrm{dH}_{2} \mathrm{O}$ & $50 \mu \mathrm{M}$ & Sigma-Aldrich & A5282 \\
\hline MPEP & non-competitive antagonist of $\mathrm{mGluR}_{5} \mathrm{~S}$ & $\mathrm{dH}_{2} \mathrm{O}$ & $10 \mu \mathrm{M}$ & Tocris & 1212 \\
\hline AM 251 & inverse agonist of $\mathrm{CB} 1 \mathrm{Rs}$ & $15 \%$ DMSO & $4 \mu \mathrm{M}$ & Tocris & 1117 \\
\hline Nimodipine & L-type $\mathrm{Ca}^{2+}$ channel blocker & DMSO & $20 \mu \mathrm{M}$ & Tocris & 0600 \\
\hline Tat-GluA2 $3 Y$ & Inhibits phosphorylation at Tyr on GluA2 & aCSF & $10 \mu \mathrm{M}$ & Yu Tian Wang, UBC & July 2018 stock \\
\hline$(R, S)-3,5-D H P G$ & group 1 mGluR agonist & $\mathrm{dH}_{2} \mathrm{O}$ & $30 \mu \mathrm{M}$ & Tocris & 342 \\
\hline Win $55,212-2$ & CB1 \& CB2 agonist & $100 \%$ DMSO & $5 \mu \mathrm{M}$ & Cayman Chemical & $10,009,023$ \\
\hline
\end{tabular}

A summary of all pharmacological agonists and antagonists used in the present study. Drugs were dissolved first as stock solutions in a vehicle solution, aliquoted then stored at $-20^{\circ} \mathrm{C}$ until experimental use. The desired compound was then added to aCSF at the concentration indicated and applied to slices according to desired paradigm of exposure.

anti-CB1 receptor antibody (1:100; Frontier Institute Co., ltd; goat polyclonal; CB1-Go-Af450; AB_2571592) together with the mouse monoclonal anti-GFAP antibody (1:1000; Sigma-Aldrich; mouse monoclonal; G3893; $\mathrm{AB} \_257130$ ) on a shaker for $2 \mathrm{~d}$ at $4^{\circ} \mathrm{C}$. Tissue was incubated in a secondary 1.4-nm gold-labeled rabbit anti-goat immunoglobulin G (Fab' fragment; 1: 100; Nanoprobes Inc., cat\#2004) and in a biotinylated anti-mouse secondary antibody (1: 200; Vector Labs; BA-2000; AB_2313581) for $4 \mathrm{~h}$ at RT. Then, sections were incubated in avidin-biotin peroxidase complex (ABC) (1:50), subsequently washed in 1\% BSA/TBS overnight at $4^{\circ} \mathrm{C}$ and postfixed in $1 \%$ glutaraldehyde in TBS for $10 \mathrm{~min}$ at RT. Gold particles were silver intensified with an HQ Silver kit (Nanoprobes Inc.) for $\sim 12 \mathrm{~min}$ (in dark). Tissue was then incubated in $0.05 \%$ diaminobenzidine $(\mathrm{DAB})$ and $0.01 \%$ hydrogen peroxide prepared in $0.1 \mathrm{M}$ PB for $3 \mathrm{~min}$. Labeled sections were osmicated ( $1 \%$ osmium tetroxide in $0.1 \mathrm{M} \mathrm{PB}, \mathrm{pH} 7.4,20 \mathrm{~min}$ ), dehydrated in graded alcohols to propylene oxide, and plastic-embedded in Epon resin 812. Ultrathin sections (50 nm thick) were collected on mesh nickel grids, counterstained with $2.5 \%$ lead citrate for 20 min and examined with a Philips EM208S electron microscope. Tissue sections were imaged using a Morada digital camera (Olympus) coupled to the electron microscope. Figures were created with Adobe Photoshop (CS3, Adobe Systems; RRID: SCR_014199).

\section{In vitro electrophysiology}

As described previously, juvenile male $(n=41)$ and female $(n=27)$ rats were used to examine LTD in the adolescent hippocampal DG (PND 21-28) (Fontaine et al. 2019). Animals were anesthetized with isoflurane until unresponsive and then rapidly decapitated. Brains were quickly removed in cold $\left(1^{\circ} \mathrm{C}-2^{\circ} \mathrm{C}\right)$ artificial cerebrospinal fluid (aCSF; $125 \mathrm{mM} \mathrm{NaCl}, 2.5 \mathrm{mM} \mathrm{KCl}, 1.25 \mathrm{mM} \mathrm{NaH}_{2} \mathrm{PO}_{4}, 25$ $\mathrm{mM} \mathrm{NaHCO}, 2 \mathrm{mM} \mathrm{CaCl}_{2}, 1.3 \mathrm{mM} \mathrm{MgCl}_{2}$ and $1.4 \mathrm{mM}$ Dextrose) equilibrated with carbogen (95\% oxygen, 5\% carbon dioxide). Transverse slices $(400 \mu \mathrm{m})$ were then cut using a vibratome (Pelco 100, Ted Pella Inc.) in the cold aCSF, before being allowed to recover in warmed $\mathrm{aCSF}\left(32 \pm 0.5^{\circ} \mathrm{C}\right)$ for at least $1 \mathrm{~h}$ prior to being used for experimentation.

For all recordings, slices were submerged in, and continuously perfused with, carbogenated aCSF at $30 \pm 0.5^{\circ} \mathrm{C}$. An upright microscope (Olympus BX51WI, Olympus) was used to visually position a concentric bipolar stimulating electrode (FHC, Bowdoinham, ME) into the middle third of the dentate molecular layer (DML) to activate medial perforant path (MPP) fibres. Extracellular field excitatory postsynaptic potentials (fEPSPs) were recorded using a glass micropipette $(1 \mathrm{M} \Omega)$, filled with aCSF, and visually positioned in the middle third of the DML to align with the stimulating electrode. fEPSP data were collected using an Axon Multiclamp 700B amplifier and recorded using Clampex 10.5 software (Axon Instruments, Molecular Devices; RRID: SCR_011323).

Electrode placement was optimized on a slice-by-slice basis. All slices included in this study had maximal fEPSP amplitudes of at least $0.7 \mathrm{mV}$. The stimulation intensity was reduced to $70 \%$ of the maximal response for all experiments. Single pulse stimulation
$(0.067 \mathrm{~Hz})$ was delivered until a stable fEPSP slope $(<10 \%$ variability) was maintained for at least $20 \mathrm{~min}$ prior to application of one of the following conditioning stimulus (CS) protocols.

\section{Paired-pulse}

Prior to the induction of LTD and at the end of the postconditioning recording, the presynaptic neurotransmitter release probability was evaluated using a paired-pulse stimulation protocol. To this end, a pair of pulses (intensity unchanged) were delivered 50 msec apart and a ratio was constructed comparing the slope of the second fEPSP relative to the slope of the first fEPSP.

\section{Conditioning protocols}

\section{$10 \mathrm{~Hz}$-LTD protocol}

As described previously, eCB-LTD was evoked by LFS consisting of 6000 pulses ( $0.24 \mathrm{msec}$ pulse width) at $10 \mathrm{~Hz}$ via the stimulating electrode as per (Peñasco et al. 2019). In these experiments, 100 $\mu \mathrm{M}$ picrotoxin (PTX; Tocris) was also included in the aCSF to inhibit $\mathrm{GABA}_{\mathrm{A}}$ receptors throughout the recording period.

\section{$1 \mathrm{~Hz}-$ LTD protocol}

As described previously, LTD was induced by delivering 900 pulses (0.24 msec pulse width) at $1 \mathrm{~Hz}$ in regular aCSF (Dudek and Bear 1992).

\section{mGIUR-LTD}

The group I mGluR agonist DHPG ((RS)-3,5-Dihydroxyphenylglycine; $30 \mu \mathrm{M}$; Tocris) was bath applied to slices in aCSF over a period of $20 \mathrm{~min}$, and the degree of depression induced was monitored during this period, with continuous single pulse stimulation $(0.067 \mathrm{~Hz})$ as previously described (Camodeca et al. 1999). Following drug exposure, regular aCSF was washed onto slices for remaining postconditioning period.

\section{Win-LTD}

The CB1 and CB2 receptor agonist Win,55 212-2 (Win; $5 \mu \mathrm{M}$; Caymen Chemical) was bath applied to slices in aCSF for 20 min during concurrent single-pulse stimulation at $0.067 \mathrm{~Hz}$. Following the drug exposure, regular aCSF was supplied to slices for the remainder of the postconditioning period.

\section{Postconditioning recordings}

In all cases, following the application of a conditioning protocol, single pulse stimulation $(0.067 \mathrm{~Hz})$ was resumed for $30-60 \mathrm{~min}$, depending on the experiment. The magnitude of LTD quantified as the average fEPSP slope for the last $5 \mathrm{~min}$ of the postconditioning recording. For the sequential administration of the two LTD stimulation paradigms (occlusion experiments), the first postconditioning recording period after the application of the $10 \mathrm{~Hz}$ 
stimulation (6000 pulses) was followed by administration of the 1 Hz LFS (900 pulses) and then by a 30 -min postconditioning recording. Our pilot work indicated that LTD is saturated following the administration of the $10 \mathrm{~Hz}$ stimulation paradigm.

\section{Pharmacology}

The antagonists N-(Piperidin-1-yl)-5-(4-iodophenyl)-1-(2,4-dichlorophenyl)-4-methyl-1H-pyrazole-3-carboxamide (AM251; $4 \mu \mathrm{M}$, Tocris Bioscience; dissolved in 15\% DMSO) 2-Methyl-6(phenylethynyl)pyridine (MPEP; $10 \mu \mathrm{M}$; Tocris Bioscience) and DL-2-Amino-5-phosphonopentanoic acid (DL-APV; $50 \mu \mathrm{M}$; Tocris Bioscience) were used to inhibit CB1, GluR $_{5}$, and NMDA receptors, respectively (Table 1 ). The antagonist nimodipine (NIMO; $20 \mu \mathrm{M}$; Tocris Bioscience) was used to block L-type calcium channels and a synthetic peptide, Tat-GluA2 ${ }_{3 \mathrm{Y}}$ (Tat-GluA2; $10 \mu \mathrm{M}$; donated by Yu Tian Wang, University of British Columbia) was used to block phosphorylation of tyrosine residues on the GluA2 classically associated with AMPAR endocytosis (Man et al. 2000; Ahmadian et al. 2004). Unless otherwise specified, receptor antagonists were dissolved in deionized water, aliquoted and stored at $-20^{\circ} \mathrm{C}$ until use when they were thawed and pipetted directly into aCSF to yield the appropriate concentration. All antagonists were applied for the last $10 \mathrm{~min}$ of the preconditioning recording period, as well as during the administration of any of the conditioning protocols with the exception of Tat-GluA2 which was applied for the complete preconditioning period, throughout the conditioning protocol and for $30 \mathrm{~min}$ of the postconditioning recording.

\section{Data and statistical analyses}

For all recordings, the average fEPSP slope is presented as the mean \pm SEM, and graphically is depicted as the average of four responses (i.e., $1 \mathrm{~min}$ ). Student's $t$-tests were used to statistically compare magnitudes of LTD. Statistical significance was set at $P<0.05$. Effect sizes were calculated as Cohen's $d$ and are provided when statistical significance was achieved.

\section{Acknowledgments}

The authors thank other members of the laboratory that aided in experimental preparation and procedures including W. Yang, K. Suesser, A. Pang, and J. Choi. This research is supported by grants from NSERC and CIHR to B.R.C. C.J.F. was supported by a Vanier CGS (NSERC). E.G. is supported by a CIHR CGS-M. C.P. is supported by the Agusti Pedro I Pons Foundation. Also, by grants from The Basque Government (IT1230-19), Red de Trastornos Adictivos, Instituto de Salud Carlos III (ISC-III) and European Regional Development Funds-European Union (ERDF-EU; RD16/ 0017/0012), MINECO/FEDER, UE (SAF2015-65034-R) to P.G. I.B.-DR. is supported by MINECO/FEDER, UE (POP contract BES-2016-076766). We thank Dr. Yu Tian Wang from the University of British Columbia for the generous donation of the Tat-GluA2 $2_{3 y}$ peptide.

\section{REFERENCES}

Ahmadian G, Ju W, Liu L, Wyszynski M, Lee SH, Dunah AW, Taghibiglou C, Wang Y, Lu J, Wong TP, et al. 2004. Tyrosine phosphorylation of GluR2 is required for insulin-stimulated AMPA receptor endocytosis and LTD. EMBO J 23: $1040-1050$. doi:10.1038/sj.emboj.7600126

Araque A, Castillo PE, Manzoni OJ, Tonini R. 2017. Synaptic functions of endocannabinoid signaling in health and disease. Neuropharmacology 124: 13-24. doi:10.1016/j.neuropharm.2017.06.017

Basavarajappa B. 2015. Fetal alcohol spectrum disorder: potential role of endocannabinoids signaling. Brain Sci 5: 456-493. doi:10.3390/ brainsci5040456

Basavarajappa BS, Hungund BL. 2002. Neuromodulatory role of the endocannabinoid signaling system in alcoholism: an overview. Prostaglandins Leukot Essent Fatty Acids 66: 287-299. doi:10.1054/plef .2001 .0352

Bastrikova N, Gardner GA, Reece JM, Jeromin A, Dudek SM. 2008. Synapse elimination accompanies functional plasticity in hippocampal neurons. Proc Natl Acad Sci 105: 3123-3127. doi:10.1073/pnas.0800027105
Bear MF, Malenka RC. 1994. Synaptic plasticity: LTP and LTD. Curr Opin Neurobiol 4: 389-399. doi:10.1016/0959-4388(94)90101-5

Camodeca N, Breakwell NA, Rowan MJ, Anwyl R. 1999. Induction of LTD by activation of group I mGluR in the dentate gyrus in vitro. Neuropharmacology 38: 1597-1606. doi:10.1016/S0028-3908(99) 00093-3

Castillo PE, Younts TJ, Chávez AE, Hashimotodani Y. 2012. Endocannabinoid signaling and synaptic function. Neuron 76: 70-81. doi:10.1016/j.neuron.2012.09.020

Chávez AE, Chiu CQ, Castillo PE. 2010. TRPV1 activation by endogenous anandamide triggers postsynaptic long-term depression in dentate gyrus. Nat Neurosci 13: 1511-1518. doi:10.1038/nn.2684

Chevaleyre V, Takahashi KA, Castillo PE. 2006. Endocannabinoid-mediated synaptic plasticity in the CNS. Annu Rev Neurosci 29: 37-76. doi:10 .1146/annurev.neuro.29.051605.112834

Christie BR. 1996. Long-term depression (LTD) in the hippocampus. Hippocampus 6: 1-2. doi:10.1002/(SICI)1098-1063(1996)6:1<1:: AID-HIPO1>3.0.CO;2-U

Christie BR, Abraham WC. 1992a. Priming of associative long-term depression in the dentate gyrus by theta frequency synaptic activity. Neuron 9: 79-84. doi:10.1016/0896-6273(92)90222-Y

Christie BR, Abraham WC. 1992b. NMDA-dependent heterosynaptic long-term depression in the dentate gyrus of anaesthetized rats. Synapse 10: $1-6$. doi:10.1002/syn.890100102

Christie BR, Abraham WC. 1994. L-type voltage-sensitive calcium channel antagonists block heterosynaptic long-term depression in the dentate gyrus of anaesthetized rats. Neurosci Lett 167: 41-45. doi:10.1016/ 0304-3940(94)91023-5

Christie BR, Kerr DS, Abraham WC. 1994. Flip side of synaptic plasticity: long-term depression mechanisms in the hippocampus. Hippocampus 4 : 127-135. doi:10.1002/hipo.450040203

Christie BR, Stellwagen D, Abraham WC. 1995. Evidence for common expression mechanisms underlying heterosynaptic and associative long-term depression in the dentate gyrus. J Neurophysiol 74: 12441247. doi:10.1152/in.1995.74.3.1244

Christie BR, Schexnayder LK, Johnston D. 1997. Contribution of voltage-gated $\mathrm{Ca} 2+$ channels to homosynaptic long-term depression in the CA1 region in vitro. J Neurophysiol 77: 1651-1655. doi:10.1152/jn .1997.77.3.1651

Cummings JA, Mulkey RM, Nicoll RA, Malenka RC. 1996. Ca2+ signaling requirements for long-term depression in the hippocampus. Neuron 16: 825-833. doi:10.1016/S0896-6273(00)80102-6

Dudek SM, Bear MF. 1992. Homosynaptic long-term depression in area CA1 of hippocampus and effects of N-methyl-D-aspartate receptor blockade. Proc Natl Acad Sci 89: 4363-4367. doi:10.1073/pnas.89.10.4363

Dudek SM, Bear MF. 1993. Bidirectional long-term modification of synaptic effectiveness in the adult and immature hippocampus. J Neurosci 13: 2910-2918. doi:10.1523/JNEUROSCI.13-07-02910.1993

Dunwiddie T, Lynch G. 1978. Long-term potentiation and depression of synaptic responses in the rat hippocampus: localization and frequency dependency. J Physiol 276: 353-367. doi:10.1113/jphysiol.1978 .sp012239

Eadie BD, Cushman J, Kannangara TS, Fanselow MS, Christie BR. 2012. NMDA receptor hypofunction in the dentate gyrus and impaired context discrimination in adult Fmr1 knockout mice. Hippocampus 22: 241-254. doi:10.1002/hipo.20890

Fontaine CJ, Patten AR, Sickmann HM, Helfer JL, Christie BR. 2016. Effects of pre-natal alcohol exposure on hippocampal synaptic plasticity: sex, age and methodological considerations. Neurosci Biobehav Rev 64: 1234. doi:10.1016/j.neubiorev.2016.02.014

Fontaine CJ, Pinar C, Yang W, Pang AF, Suesser KE, Choi JSJ, Christie BR. 2019. Impaired bidirectional synaptic plasticity in juvenile offspring following prenatal ethanol exposure. Alcohol Clin Exp Res 43: 21532166. doi:10.1111/acer.14170

Freund TF, Katona I, Piomelli D. 2003. Role of endogenous cannabinoids in synaptic signaling. Physiol Rev 83: 1017-1066. doi:10.1152/physrev .00004 .2003

García-Gutiérrez MS, Ortega-Álvaro A, Busquets-García A, Pérez-Ortiz JM, Caltana L, Ricatti MJ, Brusco A, Maldonado R, Manzanares J. 2013. Synaptic plasticity alterations associated with memory impairment induced by deletion of CB2 cannabinoid receptors. Neuropharmacology 73: 388-396. doi:10.1016/j.neuropharm.2013.05.034

Gutiérrez-Rodríguez A, Puente N, Elezgarai I, Ruehle S, Lutz B, Reguero L, Gerrikagoitia I, Marsicano G, Grandes P. 2017. Anatomical characterization of the cannabinoid CB1 receptor in cell-type-specific mutant mouse rescue models. J Comp Neurol 525: 302-318. doi:10.1002/ cne. 24066

Gutiérrez-Rodríguez A, Bonilla-Del Río I, Puente N, Gómez-Urquijo SM, Fontaine CJ, Egaña-Huguet J, Elezgarai I, Ruehle S, Lutz B, Robin LM, et al. 2018. Localization of the cannabinoid type-1 receptor in subcellular astrocyte compartments of mutant mouse hippocampus. Glia 66: 14171431. doi:10.1002/glia.23314 
Han J, Kesner P, Metna-Laurent M, Duan T, Xu L, Georges F, Koehl M, Abrous DN, Mendizabal-Zubiaga J, Grandes P, et al. 2012. Acute cannabinoids impair working memory through astroglial CB1 receptor modulation of hippocampal LTD. Cell 148: 1039-1050. doi:10.1016/j .cell.2012.01.037

Harkany T, Guzmán M, Galve-Roperh I, Berghuis P, Devi LA, Mackie K. 2007. The emerging functions of endocannabinoid signaling during CNS development. Trends Pharmacol Sci 28: 83-92. doi:10.1016/j.tips .2006.12.004

Hofmann ME, Nahir B, Frazier CJ. 2006. Endocannabinoid-mediated depolarization-induced suppression of inhibition in hilar mossy cells of the rat dentate gyrus. J Neurophysiol 96: 2501-2512. doi:10.1152/jn .00310 .2006

Hofmann ME, Bhatia C, Frazier CJ. 2011. Cannabinoid receptor agonists potentiate action potential-independent release of GABA in the dentate gyrus through a CB1 receptor-independent mechanism. Physiol Soc J Physiol 589: 15. doi:10.1113/jphysiol.2011.211482

Hubel DH, Wiesel TN, LeVay S. 1977. Plasticity of ocular dominance columns in monkey striate cortex. Philos Trans R Soc Lond B Biol Sci 278: 377-409. doi:10.1098/rstb.1977.0050

Huber KM, Kayser MS, Bear MF. 2000. Role for rapid dendritic protein synthesis in hippocampal mGluR-dependent long-term depression. Science 288: $1254-1257$. doi:10.1126/science.288.5469.1254

Kannangara TS, Eadie BD, Bostrom CA, Morch K, Brocardo PS, Christie BR. 2014. GluN2A ${ }^{-1-}$ mice lack bidirectional synaptic plasticity in the dentate gyrus and perform poorly on spatial pattern separation tasks. Cereb Cortex 25: 2102-2113. doi:10.1093/cercor/bhu017

Kano M, Ohno-Shosaku T, Hashimotodani Y, Uchigashima M, Watanabe M. 2009. Endocannabinoid-mediated control of synaptic transmission. Physiol Rev 89: 309-380. doi:10.1152/physrev.00019.2008

Katona I, Freund TF. 2012. Multiple functions of endocannabinoid signaling in the brain. Annu Rev Neurosci 35: 529-558. doi:10.1146/ annurev-neuro-062111-150420

Lee H, Kameyama K, Huganir RL, Bear MF. 1998. NMDA induces long-term synaptic depression and dephosphorylation of the GluR1 subunit of AMPA receptors in hippocampus. Neuron 21: $1151-1162$. doi:10.1016/ S0896-6273(00)80632-7

Li Y, Kim J. 2015. Neuronal expression of CB2 cannabinoid receptor mRNAs in the mouse hippocampus. Neuroscience 311: 253-267. doi:10.1016/j .neuroscience.2015.10.041

Liu L, Wong TP, Pozza MF, Lingenhoehl K, Wang Y, Sheng M, Auberson YP, Wang YT. 2004. Role of NMDA receptor subtypes in governing the direction of hippocampal synaptic plasticity. Science 304: 1021-1024. doi:10.1126/science.1096615

Malenka RC, Bear MF. 2004. LTP and LTD: an embarrassment of riches. Neuron 44: 5-21. doi:10.1016/j.neuron.2004.09.012

Man HY, Ju W, Ahmadian G, Wang YT. 2000. Intracellular trafficking of AMPA receptors in synaptic plasticity. Cell Mol Life Sci 57: 1526-1534. doi:10.1007/PL00000637

Mato S, Lafourcade M, Robbe D, Bakiri Y, Manzoni OJ. 2008. Role of the cyclic-AMP/PKA cascade and of P/Q-type $\mathrm{Ca}^{++}$channels in endocannabinoid-mediated long-term depression in the nucleus accumbens. Neuropharmacology 54: 87-94. doi:10.1016/j.neuropharm .2007.04.014

Mulkey RM, Malenka RC. 1992. Mechanisms underlying induction of homosynaptic long-term depression in area CA1 of the hippocampus. Neuron 9: 967-975. doi:10.1016/0896-6273(92)90248-C

Mulkey R, Herron CC, Malenka R. 1993. An essential role for protein phosphatases in hippocampal long-term depression. Science 261: 10511055. doi:10.1126/science.8394601

Mulkey RM, Endo S, Shenolikar S, Malenka RC. 1994. Involvement of a calcineurin/ inhibitor-1 phosphatase cascade in hippocampal long-term depression. Nature 369: 486-488. doi:10.1038/369486a0

Nahir B, Lindsly C, Frazier CJ. 2010. mGluR-mediated and endocannabinoid-dependent long-term depression in the hilar region of the rat dentate gyrus. Neuropharmacology 58: 712-721. doi:10.1016/j .neuropharm.2009.12.022

Nicoll RA, Oliet SHR, Malenka RC. 1998. NMDA receptor-dependent and metabotropic glutamate receptor-dependent forms of long-term depression coexist in CA1 hippocampal pyramidal cells. Neurobiol Learn Mem 70: 62-72. doi:10.1006/nlme.1998.3838

Oliet SH, Malenka RC, Nicoll RA. 1997. Two distinct forms of long-term depression coexist in CA1 hippocampal pyramidal cells. Neuron 18: 969982. doi:10.1016/S0896-6273(00)80336-0

O'Mara SM, Rowan MJ, Anwyl R. 1995. Metabotropic glutamate receptor-induced homosynaptic long-term depression and depotentiation in the dentate gyrus of the rat hippocampus in vitro. Neuropharmacology 34: 983-989. doi:10.1016/0028-3908(95)00062-B

Peñasco S, Rico-Barrio I, Puente N, Gómez-Urquijo SM, Fontaine CJ, Egaña-Huguet J, Achicallende S, Ramos A, Reguero L, Elezgarai I, et al. 2019. Endocannabinoid long-term depression revealed at medial perforant path excitatory synapses in the dentate gyrus.
Neuropharmacology 153: 32-40. doi:10.1016/j.neuropharm .2019 .04 .020

Peñasco S, Rico-Barrio I, Puente N, Fontaine CJ, Ramos A, Reguero L, Gerrikagoitia I, Rodriguez de Fonseca F, Suarez J, Barrondo S, et al. 2020. Intermittent ethanol exposure during adolescence impairs cannabinoid type 1 receptor-dependent long-term depression and recognition memory in adult mice. Neuropsychopharmacology 45: 309-318.

Pierrefiche O. 2017. Long term depression in rat hippocampus and the effect of ethanol during fetal life. Brain Sci 7: 157. doi:10.3390/ brainsci7120157

Pinar C, Fontaine CJ, Triviño-Paredes J, Lottenberg CP, Gil-Mohapel J, Christie BR. 2017. Revisiting the flip side: long-term depression of synaptic efficacy in the hippocampus. Neurosci Biobehav Rev 80: 394413. doi:10.1016/j.neubiorev.2017.06.001

Pöschel B, Manahan-Vaughan D. 2007. Persistent (>24h) long-term depression in the dentate gyrus of freely moving rats is not dependent on activation of NMDA receptors, L-type voltage-gated calcium channels or protein synthesis. Neuropharmacology 52: 46-54. doi:10 $.1016 /$ j.neuropharm.2006.07.019

Pöschel B, Stanton PK. 2007. Comparison of cellular mechanisms of long-term depression of synaptic strength at perforant path-granule cell and Schaffer collateral-CA1 synapses. Prog Brain Res 163: 473-500. doi:10.1016/S0079-6123(07)63026-X

Prenderville JA, Kelly ÁM, Downer EJ. 2015. The role of cannabinoids in adult neurogenesis. Br J Pharmacol 172: 3950-3963. doi:10.1111/bph .13186

Puente N, Cui Y, Lassalle O, Lafourcade M, Georges F, Venance L, Grandes P, Manzoni OJ. 2011. Polymodal activation of the endocannabinoid system in the extended amygdala. Nat Neurosci 14: 1542-1547. doi:10 $.1038 / \mathrm{nn} .2974$

Rouach N, Nicoll RA. 2003. Endocannabinoids contribute to short-term but not long-term mGluR-induced depression in the hippocampus. Eur J Neurosci 18: 1017-1020. doi:10.1046/j.1460-9568 .2003.02823.x

Safaryan K, Maex R, Davey N, Adams R, Steuber V. 2017. Nonspecific synaptic plasticity improves the recognition of sparse patterns degraded by local noise OPEN. Sci Rep 7: 46550. doi:10.1038/srep46550

Stanton PK, Sejnowski TJ. 1989. Associative long-term depression in the hippocampus induced by hebbian covariance. Nature 339: 215-218. doi:10.1038/339215a0

Stringer RL, Laufer BI, Kleiber ML, Singh SM. 2013. Reduced expression of brain cannabinoid receptor 1 (Cnr1) is coupled with an increased complementary micro-RNA (miR-26b) in a mouse model of fetal alcohol spectrum disorders. Clin Epigenetics 5: 14. doi:10.1186/ 1868-7083-5-14

Stryker MP, Harris WA. 1986. Binocular impulse blockade prevents the formation of ocular dominance columns in cat visual cortex. J Neurosci 6: 2117-2133. doi:10.1523/JNEUROSCI.06-08-02117.1986

Subbanna S, Shivakumar M, Psychoyos D, Xie S, Basavarajappa BS. 2013. Anandamide-CB1 receptor signaling contributes to postnatal ethanol-induced neonatal neurodegeneration, adult synaptic, and memory deficits. J Neurosci 33: 6350-6366. doi:10.1523/JNEUROSCI .3786-12.2013

Subbanna S, Psychoyos D, Xie S, Basavarajappa BS. 2015. Postnatal ethanol exposure alters of 2-arachidonoilglycerol-metabolizing enzymes and pharmacological inhibition of monoacylglycerol does not cause neurodegeneration in neonatal mice. J Neurochem 134: 276-287. doi:10 $.1111 /$ jnc. 13120

Taylor AH, Ang C, Bell SC, Konje JC. 2007. The role of the endocannabinoid system in gametogenesis, implantation and early pregnancy. Hum Reprod Update 13: 501-513. doi:10.1093/humupd/dmm018

Trommer BL, Liu YB, Pasternak JF. 1996. Long-term depression at the medial perforant path-granule cell synapse in developing rat dentate gyrus. Brain Res Dev Brain Res 96: 97-108. doi:10.1016/0165-3806(96) 00104-6

Vasuta C, Caunt C, James R, Samadi S, Schibuk E, Kannangara T, Titterness AK, Christie BR. 2007. Effects of exercise on NMDA receptor subunit contributions to bidirectional synaptic plasticity in the mouse dentate gyrus. Hippocampus 17: 1201-1208. doi:10.1002/hipo .20349

Wang Y, Rowan MJ, Anwyl R. 1997. Induction of LTD in the dentate gyrus in vitro is nmda receptor independent, but dependent on $\mathrm{Ca}^{2+}$ influx via low-voltage-activated $\mathrm{Ca}^{2+}$ channels and release of $\mathrm{Ca}^{2+}$ from intracellular stores. J Neurophysiol 77: 812-825. doi:10.1152/jn.1997.77 2.812

Wang Y, Wu J, Rowan MJ, Anwyl R. 1998. Role of protein kinase C in the induction of homosynaptic long-term depression by brief low frequency stimulation in the dentate gyrus of the rat hippocampus in vitro. J Physiol 513: 467-475. doi:10.1111/j.1469-7793 $.1998 .467 \mathrm{bb} . \mathrm{x}$ 
Wang Q, Chang L, Rowan MJ, Anwyl R. 2007. Developmental dependence, the role of the kinases p38 MAPK and PKC, and the involvement of tumor necrosis factor-R1 in the induction of mGlu-5 LTD in the dentate gyrus. Neuroscience 144: 110-118. doi:10.1016/j.neuroscience.2006.09 .011

Wang W, Trieu BH, Palmer LC, Jia Y, Pham DT, Jung K-M, Karsten CA, Merrill CB, Mackie K, Gall CM, et al. 2016. A primary cortical input to hippocampus expresses a pathway-specific and endocannabinoid-dependent form of long-term potentiation. eNeuro 3: ENEURO.0160-16.2016. doi:10.1523/ENEURO.016016.2016

Wang W, Jia Y, Pham DT, Palmer LC, Jung K-M, Cox CD, Rumbaugh G, Piomelli D, Gall CM, Lynch G. 2018. Atypical endocannabinoid signaling initiates a new form of memory-related plasticity at a cortical input to hippocampus. Cereb Cortex 28: 2253-2266. doi:10.1093/cercor/ bhx126
Wiegert JS, Oertner TG. 2013. Long-term depression triggers the selective elimination of weakly integrated synapses. Proc Natl Acad Sci 110: E4510. doi:10.1073/pnas.1315926110

Wilson RI, Nicoll RA. 2002a. Endocannabinoid signaling in the brain. Science 296: 678-682. doi: $10.1126 /$ science. 1063545

Wilson RI, Nicoll RA. 2002b. Endocannabinoid signaling in the brain. Science 296: 678-682. doi:10.1126/science.1063545

Wilson RI, Kunos G, Nicoll RA. 2001. Presynaptic specificity of endocannabinoid signaling in the hippocampus. Neuron 31: 453-462. doi:10.1016/S0896-6273(01)00372-5

Zhou Y, Falenta K, Lalli G. 2014. Endocannabinoid signalling in neuronal migration. Int J Biochem Cell Biol 47: 104-108. doi:10.1016/j.biocel.2013 .12 .007

Received May 25, 2020; accepted in revised form July 2, 2020. 


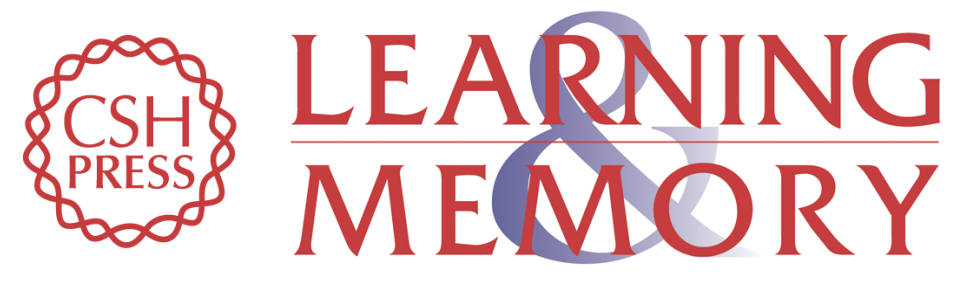

\section{Endocannabinoid receptors contribute significantly to multiple forms of long-term depression in the rat dentate gyrus}

Christine J. Fontaine, Erin L. Gräfe, Cristina Pinar, et al.

Learn. Mem. 2020, 27:

Access the most recent version at doi:10.1101/Im.050666.119

\begin{aligned} & \hline References $\begin{array}{l}\text { This article cites } 78 \text { articles, } 13 \text { of which can be accessed free at: } \\ \text { http://learnmem.cshlp.org/content/27/9/380.full.html\#ref-list-1 }\end{array} \\ & \begin{array}{r}\text { Creative } \\ \text { Commons } \\ \text { License }\end{array} \begin{array}{l}\text { This article is distributed exclusively by Cold Spring Harbor Laboratory Press for the } \\ \text { first } 12 \text { months after the full-issue publication date (see } \\ \text { http://learnmem.cshlp.org/site/misc/terms.xhtml). After } 12 \text { months, it is available under } \\ \text { a Creative Commons License (Attribution-NonCommercial } 4.0 \text { International), as } \\ \text { described at http://creativecommons.org/licenses/by-nc/4.0/. }\end{array} \\ & \begin{array}{c}\text { Receive free email alerts when new articles cite this article - sign up in the box at the } \\ \text { top right corner of the article or click here. }\end{array} \\ & \begin{array}{l}\text { Service } \\ \text { terting }\end{array}\end{aligned}$ 